\title{
Conceptualising the Sustainable Energy Security Dimensions of Malaysia: A Thematic Analysis through Stakeholder Engagement to Draw Policy Implications
}

\author{
Saleh Shadman $1, * \mathbb{(}$, Marlia Mohd Hanafiah ${ }^{2,3, *}$, Christina May May Chin ${ }^{1} \mathbb{D}$, Eng Hwa Yap $4(\mathbb{D}$ \\ and Novita Sakundarini ${ }^{1}$ \\ 1 Department of Mechanical, Materials, and Manufacturing Engineering, University of Nottingham Malaysia \\ Semenyih 43500, Selangor, Malaysia; Christina.chin@nottingham.edu.my (C.M.M.C.); \\ Novita.sakundarini@nottingham.edu.my (N.S.) \\ 2 Department of Earth Sciences and Environment, Faculty of Science and Technology, \\ Universiti Kebangsaan Malaysia, Bangi 43600, Selangor, Malaysia \\ 3 Centre for Tropical Climate Change System, Institute of Climate Change, Universiti Kebangsaan Malaysia, \\ Bangi 43600, Selangor, Malaysia \\ 4 School of Robotics, XJTLU Entrepreneur College, Xi'an Jiaotong-Liverpool University, Suzhou 215123, China; \\ EngHwa.Yap@xjtlu.edu.cn \\ * Correspondence: saleh1shadman@gmail.com (S.S.); mhmarlia@ukm.edu.my (M.M.H.)
}

Citation: Shadman, S.; Hanafiah, M.M.; Chin, C.M.M.; Yap, E.H.; Sakundarini, N. Conceptualising the Sustainable Energy Security Dimensions of Malaysia: A Thematic Analysis through Stakeholder Engagement to Draw Policy Implications. Sustainability 2021, 13, 12027. https://doi.org/10.3390/ su132112027

Academic Editors: Abdul Wadood and Herie Park

Received: 17 September 2021

Accepted: 25 October 2021

Published: 31 October 2021

Publisher's Note: MDPI stays neutral with regard to jurisdictional claims in published maps and institutional affiliations.

Copyright: (c) 2021 by the authors. Licensee MDPI, Basel, Switzerland. This article is an open access article distributed under the terms and conditions of the Creative Commons Attribution (CC BY) license (https:/ / creativecommons.org/licenses/by/ $4.0 /)$.
Abstract: This study aims to provide established knowledge of the multi-dimensional concept of energy security through engaging stakeholders and experts. Energy security policy implications have been suggested in this study to address and mitigate energy security challenges. A total of seven emerging themes from semi-structured interviews have been discussed in-depth to understand the role of each theme and their interactions with energy policies. There is an urgent need to reduce dependency on fossil fuels and to look for alternative fuel options from renewable sources. At the same time, energy-efficient technology plays a significant role in improving overall efficiency and leading to reduced wastage of energy. This would, in turn, improve the availability and affordability of energy in Malaysia. Energy equity gets the most emphasis in the energy trilemma of Malaysia; however, equal importance should be attached to the nation's energy security alongside environmental sustainability. The final decision of the trilemma balance and the energy policies that govern the energy use framework depends on the ministries and the regulatory bodies. An indicator mapping process has been recommended for these themes to quantify energy security by developing an energy security index. The thematic results discussed in this study have the potential to facilitate policymakers and energy analysts of countries with similar energy outlooks to design data-driven energy security policies.

Keywords: energy security; stakeholders; sustainability; energy economics; environmental policy; energy policy; policy implication; renewable energy; energy security index

\section{Introduction}

The aim for developing nations has always been to obtain energy resources at an affordable price with supply security while ensuring minimal environmental impacts [1]. Kumary and Tewary (2021) [2] have mentioned that the world is now striving towards the use of cleaner energy resources to achieve energy security (ES) which is often disrupted by the rise in the population [3] and by unprecedented urban development. ES is a multidimensional phenomenon that can be conceptualised based on several factors, such as the energy demand pattern, export or import-dependencies [4], the geopolitics of resources, the energy policy structure of a nation, etc. It is vital to understand which of these factors dominates within a country's energy framework that further defines the ES of that respective nation. Ashari (2013) [4] has stated that ES, which used to be a non-traditional 
security issue, now plays a key role in the national security of any nation. Winzer (2011) [5] believes that the lack of a consolidated ES definition has made it difficult to measure and balance it against other policy objectives. Over the years, researchers have defined ES in several ways that indicate the existence of numerous dimensions within this complex system of ES. Table 1 represents a few simplified definitions of ES.

Table 1. Definitions of ES as quoted by researchers.

\begin{tabular}{ll}
\hline Source & Definition \\
\hline$[6]$ & $\begin{array}{l}\text { "Feature (measure, situation, or status) in which a related system functions optimally } \\
\text { and sustainably in all its dimensions, freely from any threats." }\end{array}$ \\
\hline$[7]$ & $\begin{array}{l}\text { "ES not only relies on the global flow of primary and secondary energies but also on } \\
\text { the trade of goods and services produced using energy." }\end{array}$ \\
\hline$[8]$ & $\begin{array}{l}\text { "Enough energy supply (quality and quantity) to meet all requirements at all times of all } \\
\text { citizens in affordable and stable price, and it also leads to sustained economic performance } \\
\text { and poverty alleviation, a better quality of life without harming the environment." }\end{array}$ \\
\hline$[9]$ & $\begin{array}{l}\text { "Assessing various types of risk in the energy system." } \\
{[10]}\end{array} \quad \begin{array}{l}\text { "The energy supply to a nation must be adequate and reliable, and energy prices must } \\
\text { be affordable to the population." }\end{array}$ \\
\hline "Sufficient availability of energy at all times at an affordable price to ensure consumer \\
satisfaction coupled with a gradual improvement in environmental sustainability to \\
ensure better ES."
\end{tabular}

Dincer and Acar (2015) [12] have highlighted ES as a formidable task to fulfil rising energy demands in an environmentally sustainable and long-term approach, particularly for developing countries. Safari et al., (2019) [13] have mentioned how the economic growth of a country takes a toll on the environment leading to environmental constraints. In Malaysia, there has been a rise in energy consumption within the industrial and commercial sectors due to an increase in economic activities and an increase in population from 28 million in 2010 to 32 million in 2019. This will eventually lead to a rise in energy demand by $5-7 \%$ annually in the next two decades $[14,15]$. To meet this ever-increasing demand, the energy supply is expected to be $11,400,000 \mathrm{MW}$ by 2030 , an average increase of $4.7 \%$ annually [14]. In Malaysia, natural gas, coal, and oil dominate the conventional power generation system and the total primary energy supply (TPES) [14].

Ludin et al., (2018) [16] has stated that climate change, mining of fossil fuels, depletion of natural resources, and lack of RE sources are the key challenges for Malaysia. The heavy dependency on non-renewable resources imposes a threat to Malaysia's ES [17]. Hence, it is of utmost importance to meet this increase in demand in a manner that is sustainable for the energy resources, environmentally friendly, and at the same time affordable and reliable in terms of supply security. Major stakeholders and the Malaysian government had acknowledged the significance of diversifying the fuel mix to improve national energy security, and in 1981, a new policy was implemented [18]. However, fuel diversification policies in Malaysia only had partial success in the past [18]. The government of Malaysia implemented several energy policies that targeted energy sustainability and security since 1981, with special attention attached to the supply side security of energy [19], hence focusing more on natural gas, coal, and oil. The current target by the government is to maintain a Herfindahl-Hirschman Index (HHI) of below 0.5 by 2025 for the diversification of the fuel mix to ensure an improved ES [20].

Daniel Yergin (2006) [21] has stated that diversification will remain the essential starting point of ES for both oil and gas. Today, however, it will almost certainly necessitate the development of a new generation of nuclear and "clean coal" technologies and the encouragement of a more significant role for a range of renewable energy sources as they become more competitive. It will also necessitate investment in new technologies, ranging from those that are now available, such as the conversion of natural gas into liquid fuel, to 
others that are in the lab, such as energy supply biological engineering. Today, investment in technology across the energy spectrum is soaring, which will have a beneficial impact on the future of energy and the environment. Yergin emphasises that energy is not a problem that occurs in a controlled silo. The book's greatest strength is its ability to extract generally practical ideas from history lessons, high-level technical overviews, and enlightening stories. Interconnections with major worldwide events exist in the energy realm, as Yergin demonstrates [22].

Gasser (2020) [23] has pointed out the importance of stakeholder engagement to minimise subjectivity while selecting the ES dimensions. The lack of stakeholder engagement has been identified as one of the major gaps in Malaysia's ES research. The following studies [24-27] attempted to quantify ES for Malaysia by developing an energy security index (ESI) using different dimensional frameworks. At the same time, the study of Foo (2015) [28] discusses in depth the various energy profiles of Malaysia and the development of energy policies towards ES. Khattak et al., (2018) [29] reviewed the ES status of Malaysia and the strategic approach to enhance the future of ES in Malaysia. It is worth mentioning that none of these studies had involved stakeholders in identifying the key dimensions of ES for Malaysia to validate the results obtained.

In this study, the various ES dimensions have been studied in-depth by engaging stakeholders from Malaysia, Singapore, and the Philippines to understand the criticality of the different dimensions towards paving a pathway for ES policies in Malaysia. Thematic analysis has been performed from the emerging themes of semi-structured interviews with the stakeholders. One of these themes of "Role of renewable energy in ES" has been analysed by Shadman et al., (2021) [30]. These themes have been discussed thoroughly from the stakeholders' perspective to develop substantial knowledge of ES that would facilitate making an ESI to assess ES quantitatively. A total survey of 117 participants from Malaysia's energy sector has also been conducted to consolidate the concept of ES by developing a causal relationship between the dimensional indicators. The first objective is to identify the key dimensions of ES for Malaysia that would lead to the second objective of the selection of indicators for these dimensions using an indicator mapping process. This will eventually lead to policy suggestions and implications that can facilitate the nation's policymakers to incorporate ES in their future action plans. Upon fulfilling these two objectives of the research, it will be easy to design an ESI to quantify ES for Malaysia or any other country with a similar energy outlook and profile.

\section{Exploring the Concept of Securitisation of Energy through Copenhagen School Theory}

Barry Buzan, Ole Waever, Jaap de Wilde, and others of the Copenhagen school created securitisation, so named since most of their publications appeared in the 1990s at the Conflict and Peace Research Institute (COPRI) in Copenhagen. The concept of securitisation is most fully developed in Security: A New Framework for Analysis (1998) [31,32], which draws on Waever's reflections in Securitization and Desecuritization (1995) [33], Concepts of Security (1997), and several unpublished manuscripts, such as Security, the Speech Act (1989a) [34]. The Copenhagen School intended to offer the field an analytical framework of securitisation and desecuritisation to prevent security studies from becoming too broad and, therefore, losing their relevance [35].

The Copenhagen school of security can be quoted as "securitisation is the move that takes politics beyond the established rules of the game and frames the issue either as a special kind of politics or as above politics." In the case of energy, the Copenhagen School advocated expanding the de-securitising problems and relationships while recognising existential security concerns about the state's existence (securitisation). Within the idea of security, the school also advises to just be concerned with urgent problems endangering the referent object's life. The Copenhagen School emphasises that there will be various' referent objects' depending on the relevant security sectors; these sectors encompass both classic and non-traditional concerns to be securitised [36]. As a result, energy has become widely acknowledged as a critical facet of security studies as a non-traditional security 
problem in recent decades. Energy securitisation has become a more pressing concern under the new security framework because the economy, military, and technology heavily rely on energy.

\section{Methods}

The identification of the key ES dimensions of Malaysia is made in two stages in this research. The previous study by S Shadman et al., (2021) [37] is a detailed version of the methods used to obtain the results in this research. Firstly, it is essential to carry a critical review of the energy policies of Malaysia by studying their objectives and their outcomes since their inauguration. Secondly, engaging stakeholders with SSI's and Google surveys to extract and analyse data that would otherwise be unavailable in literature or policy documentation. The latter is not commonly practised within ES research; therefore, this approach has been taken to make a deep dive into Malaysia's ES from the stakeholders' opinion. Sovacool et al., (2011) [38] has taken this similar approach to collect data through 68 SSI's and 74 survey participants, which have opened up the opportunity for a similar approach towards ES research to consolidate the concept.

\subsection{Stages of Data Collection}

To fulfil one of the key research objectives, the data collection and curation have been carried out with utmost care and priority. Data are collected in two stages: (1) SSI's with 16 stakeholders and (2) Survey with 117 participants from the private and public energy sector, and the steps have been explained in Table 2.

Table 2. Data collection procedure.

\begin{tabular}{|c|c|c|}
\hline Sampling & Instrument/Tool & Data Collection Procedure \\
\hline \multirow{3}{*}{$\begin{array}{l}\text { Selection of stakeholders and } \\
\text { interviewees from } \\
\text { government organisations, } \\
\text { private sector, and research } \\
\text { institutions. }\end{array}$} & \multirow{3}{*}{$\begin{array}{l}\text { Designing Semi-Structured } \\
\text { Questions for Interview of } \\
\text { stakeholder } \\
\text { Quantitative data collection } \\
\text { from energy data and reports } \\
\text { published in the public } \\
\text { domain by the ministry and } \\
\text { regulatory bodies. }\end{array}$} & $\begin{array}{l}\text { Conducting Semi-Structured } \\
\text { Interviews }\end{array}$ \\
\hline & & $\begin{aligned}>\quad & \text { Face-to-face } \\
>\quad & \text { Video Call with } \\
& \text { researchers abroad }\end{aligned}$ \\
\hline & & $\begin{array}{l}\text { Transcription of the } \\
\text { interviews that were recorded. }\end{array}$ \\
\hline $\begin{array}{l}\text { Selection of survey } \\
\text { participants from employees } \\
\text { within the public and private } \\
\text { energy sector in Malaysia }\end{array}$ & $\begin{array}{l}\text { Google Survey with simple ES } \\
\text { indicator-based true/false } \\
\text { questionnaire. }\end{array}$ & $\begin{array}{l}\text { Documentation of the overall } \\
\text { survey results in the form of a } \\
\text { percentage of true/false } \\
\text { recorded. }\end{array}$ \\
\hline
\end{tabular}

\subsection{Stakeholder Selection and Justification}

The samples for the interview in this study are targeted towards the ministries, government agencies, research institutions, and private organisations that work directly with ES policies and dimensions. The survey participants have been selected in terms of their field of work within the energy sector in Malaysia. In the Grounded Theory (GT) technique of coding, the sample size is also determined by the amount of available data. Data saturation is crucial for qualitative outcomes, as data quality and validity might be harmed if saturation is not achieved $[39,40]$. There is no "one-size-fits-all" method to data saturation because of the differences in study design depending on whether it is an ethnography, meta-analysis, or phenomenological study [40]. A single researcher has performed the entire data collection [41] with specific time constraints; hence, the number of stakeholders chosen is deemed to be sufficient for obtaining emergent themes as a result of the semistructured interviews (SSI) and the Google survey. Figure 1 is a flow chart representing the process of stakeholder selection. 
Identifying the key stakeholders<smiles>C=CC=C</smiles>

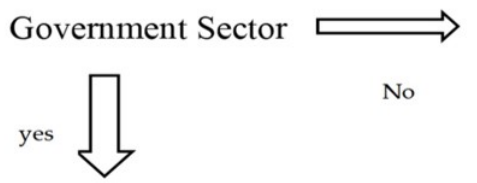

What is their role in fortifying ES for Malaysia?<smiles>CC=CC</smiles>

Directly involved in decision-making and implementation of different energy policies.<smiles>C1=CCCC1</smiles>

Ministry of energy and natural resources,

SEDA, Tenaga Nasional, Suruhanjaya

Tenaga, Institute of Strategic and

International Studies Malaysia
Research institutes and the Private sector in Malaysia or any other ASEAN country<smiles>C1CCCC1</smiles>

Energy policies, sustainable energy, renewable energy, and energy security should all be included in publications. This study is intended to assist in addressing ES difficulties, ES frameworks, ES index, and ways for resolving concerns.

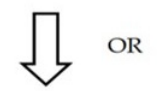

A researcher with five publications or above in Energy Security and policy of Malaysia/ASEAN region.

Figure 1. Stakeholder justification process stated in our previous study of [30].

The stakeholder selection process has led to a final selection of 16 stakeholders listed down in Table 3.

Table 3. List of Stakeholders.

\begin{tabular}{|c|c|}
\hline Stakeholder & Organisation \\
\hline 1 & Energy Commission, Malaysia \\
\hline 2 & Energy Commission, Malaysia \\
\hline 3 & Energy Studies Institute, National University of Singapore \\
\hline 4 & UiTM Energy and Facilities and UiTM Solar Power, Malaysia \\
\hline 5 & Energy Studies Institute, National University of Singapore \\
\hline 6 & Saab-NTU Joint Lab, Nanyang Technological University, Singapore \\
\hline 7 & Tenaga Nasional Berhad Malaysia \\
\hline 8 & Agilent Technologies, Malaysia \\
\hline 9 & University of Technology Sydney, Australia \\
\hline 10 & Energy Studies Institute, National University of Singapore \\
\hline 11 & Institute of Strategic and International Studies Malaysia \\
\hline 12 & Institute of Strategic and International Studies Malaysia \\
\hline 13 & Ministry of Energy and Natural Resources, Malaysia \\
\hline 14 & Sustainable Energy Development Authority (SEDA), Malaysia \\
\hline 15 & Tenaga Nasional Berhad Malaysia \\
\hline 16 & Single Buyer, Malaysia \\
\hline
\end{tabular}




\subsection{Designing the Research Instrument}

Turner (2010) [42] indicates important steps to be followed when designing the semistructured interview questions. Charmaz (2014) [43] explained that it is imperative to frame the right questions to extract the best possible data. This approach necessitates the development of abilities that researchers might acquire as they conduct more interviews on various themes. The interview questions must go into the issue and be tailored to the participant's background [43]. The study questions are versatile, allowing the respondent to respond with their unique perspective. In his book "Research Design", Creswell advises that the questions be written in such a way that the interviewee remains focused on the context of the inquiry. Table 4 contains a brief summary of the questions posed to the stakeholders.

Table 4. Non-exhaustive list of SSI questions.

\begin{tabular}{|c|c|}
\hline & Stakeholder Interview Questions \\
\hline 1 & How would you define Energy security? \\
\hline 2 & $\begin{array}{l}\text { Why is it important for us to address Energy Security challenges and their impacts? } \\
\text { Is there any specific energy policy that addresses the Energy Security of your }\end{array}$ \\
\hline 3 & $\begin{array}{l}\text { country? What more can be added to the existing policies to address the energy } \\
\text { security of Malaysia? }\end{array}$ \\
\hline 4 & $\begin{array}{l}\text { Socio-economy, Environmental Sustainability, and Energy Availability are listed as } \\
3 \text { key dimensions of Energy security that we can name. Is there any other dimension } \\
\text { that can be added and why? }\end{array}$ \\
\hline 5 & $\begin{array}{l}\text { Can you suggest ways to improve the Energy Security scenario and tackle the } \\
\text { challenges of Malaysia and other ASEAN countries? }\end{array}$ \\
\hline 6 & $\begin{array}{l}\text { What are your thoughts on quantifying energy security using an energy security } \\
\text { index and system dynamics modelling? What other ways can you suggest } \\
\text { quantifying the energy security of Malaysia? }\end{array}$ \\
\hline
\end{tabular}

On the other hand, a total of 33 survey questions were designed to understand the preliminary concept of the ES indicator relationship that we have developed from literature and energy policy knowledge.

\subsection{Grounded Theory Approach of Qualitative Data Analysis}

The data collection is carried out using semi-structured interviews lasting 40-60 min with the stakeholders before the grounded theory (GT) is applied to analyse these recorded and transcribed data [44]. The first author of this research does the transcription and recording of the data. The GT has an inductive approach of concluding theories and frameworks from observations [45]. According to the research, GT is a naturally flexible yet complicated approach to implement Chun Tie et al., (2019) [46]. As explained by Charmaz stated by Hesse et al., (2004) [47], the inductive approach is shown in Figure 2. Figure 3 shows the iterative process of coding using the GT approach.

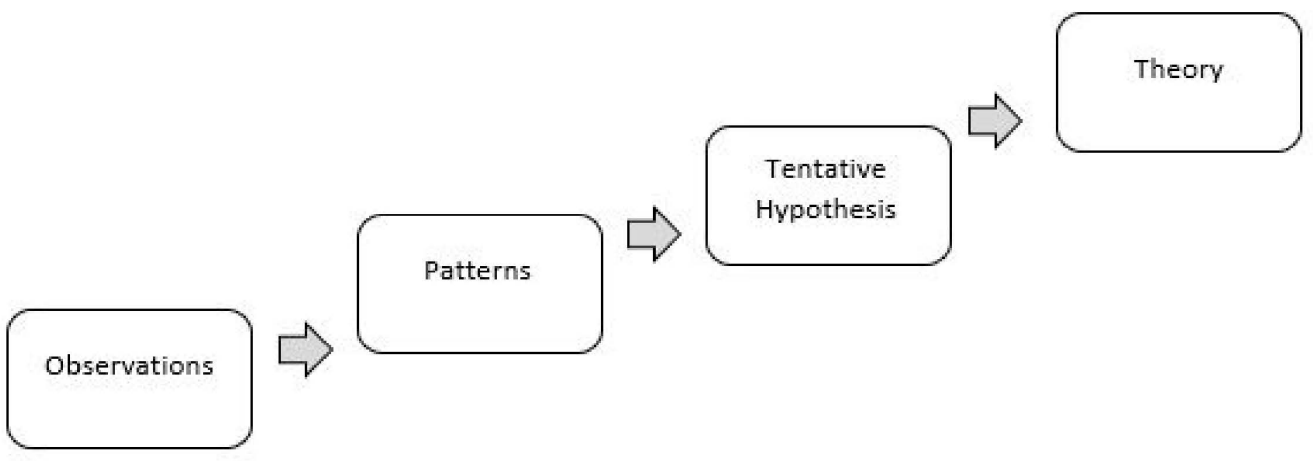

Figure 2. Inductive approach in grounded theory. 


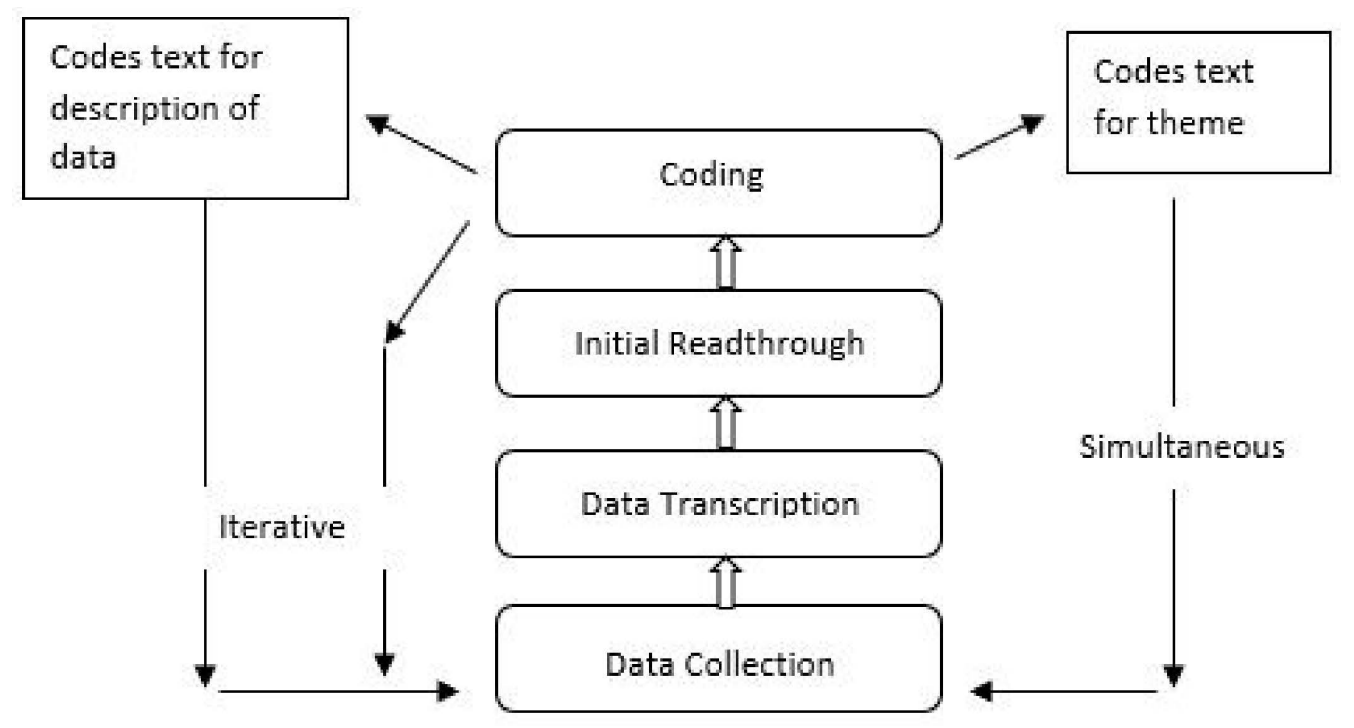

Figure 3. The iterative process as explained by Charmaz [47].

In this study, a combination of emergent coding and structural coding was shown to be the most effective method for analysing the SSI data. The data preparation step occurs once the sample size has been set and the data has been collected. Before coding, the obtained data is transcribed using an intelligent verbatim transcription approach and extensively read. The constructivist approach by Charmaz (2014) [43] of the GT, involves primarily two stages of coding: initial coding and focused coding. Following line-by-line coding and reading the text fragments and coding them as we read through the analytical import, the first coding is completed. Focused coding is the process of selecting the most appropriate and relevant codes from an initial code set, comparing data with data, and then comparing data with codes. This is also known as the constant comparative analysis [46] where new concepts are produced by comparing occurrences in one category to other events and categories inside the framework on a regular basis.

\section{Results and Discussion}

\subsection{Survey}

The survey in this research was used as a pilot study that builds up towards the SSIs conducted with stakeholders. The survey results allow us to understand the correlation between several ES indicators that we have come across in the literature. Understanding these relationships is vital to frame the correct questions to the stakeholders and develop strong evidence and a data-driven framework to assess the ES of Malaysia. Key challenges that were taken into account before developing the survey were:

- Over-dependence on fossil fuel.

- Not moving towards self-sufficiency when it comes to energy production in own country or any source of clean energy technology.

- As of 2011, oil reserves are expected to last for the next 25 years and gas reserves for 39 years.

- The current power production and demand trends show that Malaysia has a reserve margin that will last only a few years. This calls for further investment, research, and development in the country's power sector to meet the ever-increasing energy demand. The government's diversification policy and power sector expansion plan emphasise the incorporation of renewable energy sources (RESs) and other less $\mathrm{CO}_{2}$ emitting sources like nuclear into the national energy mix.

- The primary energy demand growth rate is $6.3 \%$. The latest import and export data for 2018 are collected from the Malaysia Energy Statistics Handbook 2020 [48]. 
$>\quad$ Petroleum Products: Import- 55.2\% and Export- $44.8 \%$, hence net importer of petroleum products.

$>\quad$ Crude Oil: Import- 38.1\%, Export- 61.9\%; hence net exporter of crude oils.

$>$ Coke and Coal: Import- $100 \%$, Export- $0 \%$; hence all the coal is imported.

> Natural Gas: LNG Export- 75.6\%, LNG Import- 4.0\%, Piped Natural Gas Import- $16.3 \%$, Piped Natural Gas Export- $4.1 \%$; hence net exporter of LNG and net imported of piped NG.

- The final energy consumption growth rate between $2009-2019$ was $3.1 \%$ and 2020 4.11 Exajoule (EJ), consumption by fuels only 0.04 EJ RES-0.18 EJ Hydro, Oil and Gas (1.38 EJ and 1.37), and coal 1.14 EJ [49].

- Total final energy consumption will rise from 59.88 Mtoe in 2017 to 177.18 Mtoe in 2050 under BAU, a 3.3\% annual growth rate. Natural gas usage will have the best Average Annual Growth Rate (AAGR) of 3.7\% to 2050. From 2017 to 2050, oil consumption will rise from 28.27 Mtoe to 82.17 Mtoe (a 3.3\% annual increase), coal demand will rise $3.2 \%$ each year, and power demand will rise from 12.60 Mtoe to 34.23 Mtoe (a 3.2\% annual increase) (an AAGR of 3.1\%). Demand for alternative fuels, such as biodiesel, is anticipated to rise from 0.38 Mtoe to 0.53 Mtoe, representing a $1.0 \%$ annual growth rate [50].

A total of 200 survey sheets were distributed, out of which 117 responses were recorded. This gives us an approximation of a 58.5\% feedback rate; 30 questions out of 33 have a positive response in terms of the agreement, which is within the expectation of this research. The survey questions with a high disagreement of above $35 \%$ have been pointed out in this study. Three out of 33 questions have a higher dispute than $35 \%$, as shown in Table 5.

Table 5. Survey results with high disagreement.

\begin{tabular}{ll}
\hline Question 7: & \\
\hline Cause: Increase in country's unemployment & Effect: Decrease in energy consumption \\
\hline Agree: $55 \%$ & Disagree: $45 \%$ \\
\hline Question 26: & \\
\hline Cause: Decrease in environmental impact & Effect: Decrease in energy consumption \\
\hline Agree: $56.7 \%$ & Disagree: $43.3 \%$ \\
\hline Question $27:$ & \\
\hline Cause: Decrease in energy consumption & $\begin{array}{l}\text { Effect: Decrease in renewable resources in the } \\
\text { energy mix }\end{array}$ \\
\hline Agree: $53.3 \%$ & Disagree: $46.7 \%$ \\
\hline
\end{tabular}

In the final part of the survey, two optional questions were listed: $59.1 \%$ agreed to the first question in Figure 4. This document argues that Malaysia's energy and land reserves may be exploited to support the cohabitation of energy security and economic growth in the country. According to others who disagree, other elements assure Malaysia's energy security and require interviews to extract more specific information on these indicators. The second question shows an agreement of only $36.36 \%$. Most of them feel that there needs to be more dimensions and indicators that need to be added to any existing framework to consolidate the ES concept within the Malaysian context. 


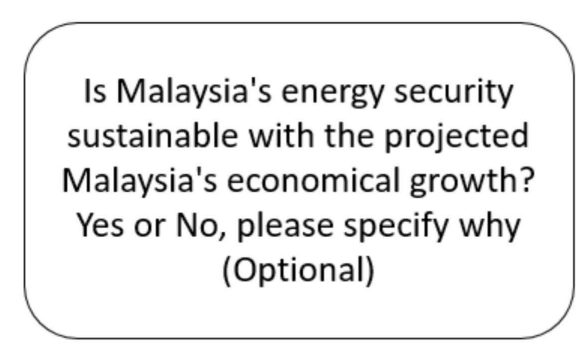

Yes (13)

$$
\text { No (9) }
$$

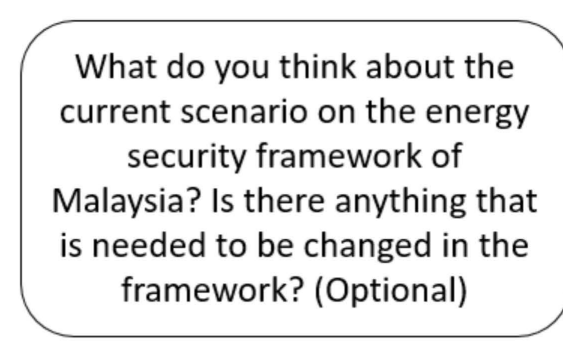

Yes (4)

No (7)

Figure 4. Optional questions.

\subsection{Emerging Themes from the Semi-Structured Interviews}

The participants' agreement is obtained before the SSIs are recorded to produce intelligent verbatim transcripts that are analysed using the programme 'Quirkos,' which provides a better insight into the data acquired through these SSIs. Stakeholders in other countries are reached via video calls, and SSIs have also been performed by video call [51]. This is a more accessible, cost-effective, and convenient option to conduct one-on-one interviews with stakeholders who are not residing in Malaysia. The names of the participants are confidential as per the research ethics guidelines, and only the list of stakeholders is shown in Table 3. Figures 5 and A1 represent the Quirkos dashboard, and the emerging themes are available in Appendix A.

\section{Securitisation process}

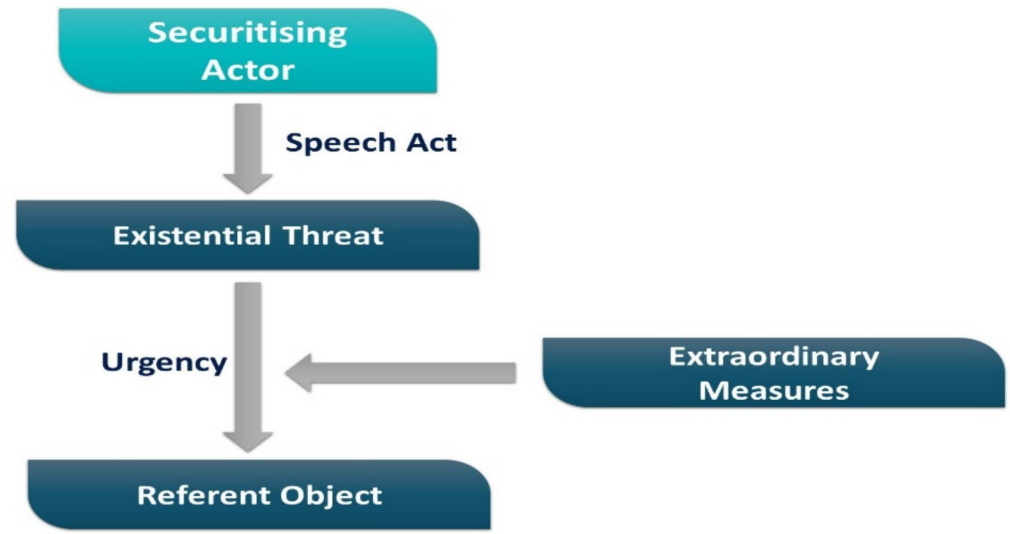

Figure 5. The securitisation framework based on the Copenhagen school.

A total of seven important emerging themes and energy policy implications have been shortlisted from the Quirkos database after coding the 16 interview transcripts. The data collected from the stakeholders have been compiled and tabulated according to these themes, and the findings have been presented here in this section. The results section is solely based on the stakeholders' perspective, and nothing has been quoted from the literature or energy policies. The term stakeholder has been referred to as "ST" in the following sections.

1. Renewable Energy.

2. Fossil Fuels.

3. Applicability of Technology.

4. 4 A's of Energy Security.

5. Environmental Sustainability.

6. Economic Development.

7. The Role of Governance. 


\subsubsection{Renewable Energy}

Acar (2018) [52], Kaya et al., (2021) [53], and Safari et al., (2019) [13] believes that RE can be a promising choice to address climate change issues and ES if the issues of intermittency and discontinuous supply can be overcome. This can be carried out using energy storage options that are affordable, reliable, and efficient at the same time. RE has always been preferred as a very clean and sustainable source of energy [54]. The study of Vaka et al., (2020) [55] is detailed research carried out on the impact of the covid-19 pandemic on solar energy and RE in Malaysia. Kim et al., (2020) [56] has suggested using RE and nuclear energy in alliance with each other to sustain the global energy demands. Shadman et al., (2021) [30] has discussed the SWOT analysis results of RE research as one of the themes of the stakeholder interview results. A pivotal study by Kardooni et al., (2016) [57] has highlighted that people in peninsular Malaysia perceive that RE requires a high level of effort, hence creating a negative attitude towards the RE technologies impairing the share of RE in the energy mix.

The results suggest that the strength of RE in Malaysia lies within the strong national energy policies, including the RE policies and the green technology policies to strengthen the share of RE as major fuel in both TPES and electricity generation. These policies are regulated by regulatory bodies like the sustainable energy development authority (SEDA) and the energy commission. The intentions are vital to reaching the target of $20 \% \mathrm{RE}$ penetration by 2025 . The intermittency challenges will always exist for RE sources for electricity generation mostly [58]. The capital cost increases due to the need for thermal powerplants to back the intermittency challenges of RE. Thus, increasing the overall costper-unit of the energy supplied. The price per unit in $\mathrm{kWh}$ is not competitive enough to cope with fossil fuels like coal and natural gas. Poor supply of electricity or energy as a whole can lead to consumer dissatisfaction which is not desired.

The RE policies and targets currently in place need to be implemented well enough to achieve the given targets. Malaysia has many opportunities to explore more solar [59], marine RE sources, and biomass-based fuels like biogas [60]. Hanafiah et al., (2010) [61] has emphasised reducing carbon emission in the ecological footprint through the promotion of biogas and bio-based fuels in the energy mix. Neighbouring countries like Singapore have utilised the opportunity to implement floating solar farms; this similar prospect is possible in Malaysia. The new targets for RE have been projected to increase to $40 \%$ by 2035 , and solar usage is expected to reach $30 \%$ of the projected peak demand in 2035 [20]. These targets are motivating towards an overall betterment for the ES of the nation.

\subsubsection{Fossil Fuels}

All the stakeholders involved in this research have agreed to the fact that fossil fuels like coal, oil, and natural gas will be irreplaceable as fuels from the TPES and electricity generation in Malaysia, backed by studies like Zakaria et al., (2021) [62] and Hannan et al., (2018) [63]. The energy mix is still dominated by more than $90 \%$ of fossil fuels [30], while it is projected that by the end of 2030, the coal share will reduce from $37 \%$ in 2021 to $22 \%$ in power generation [20]. Whether this is feasible is yet to be proven, given that the dependency on fossil fuels is still very high. ST1 believes that the use of coal and gas is not expected to change till 2025 as the Power purchase agreement (PPA) is still in effect till 2025. ST2 believes that downstream activities bring in many benefits like employment, improved standard of living, and infrastructure development. In Malaysia, downstream activities are going well with almost 30 years in operation with one of the recent Pengerang Integrated Petroleum Complex (PIPC) developments in Johor.

ST4 has stated that larger economies like China's contribution towards climate change can impact it, while more minor contributors like Malaysia will not significantly affect climate change issues with the use of fossil fuels. ST4 also stated that coal power capacity is around $8000 \mathrm{Mw}$ with ITP and TNB compared to 500,000 MW in China. Almost all the stakeholders have also discussed how the trade of higher-grade oil in return for lower grade oil, which is later refined, benefits the economy immensely due to a positive trade-off. 
ST9, in support of this, has stated that Malaysia leverages the ability of Petronas and their connection all over the world. They are comfortable in terms of petroleum as they have both domestic and international profiles for fossils. Petronas has good cooperation with other companies in Japan and Korea and can shift cargo quickly. This reflects upon the collaboration between these countries and their geopolitics.

ST14 is quoted "We are moving into a globalised era where trade is an important aspect. Trade of fossil fuels will help the world evolve in import and export in exchange for economic growth." Sutrisno et al., (2021) [64] has backed this statement of ST14 and mentioned the importance of contracts and flexibility of energy infrastructures within the global energy market. ST13 has also reflected upon the boundaries set by energy policies to ensure fair usage of the resources, and sustainably, e.g., the national depletion policy for crude oil allows the use of 700,000 barrels per day, which could be otherwise pumped up to 1 million barrels per day.

\subsubsection{Applicability of Technology}

The world is chasing new technology and improving existing energy technologies to improve efficiency and cost-effectiveness $[65,66]$. Technological advancement is one of the key dimensions in determining whether a country is heading towards long-term ES or not. "Necessity is the mother of innovation", stated by ST6 means; we move towards new technology and innovation when we are left with no choice but to do so. In the case of Singapore, a resource-scarce country, technology can play a vital role. This is backed up by ST5, where he feels there is a need to improve technology, given that Singapore is a first-world country and should lead the way forward in the ASEAN region. ST5 has also mentioned that technology can make a huge difference in national energy supply, local energy access, and poverty alleviation. The most feasible technology arriving at the right time is the key. The question remains whether Malaysia is willing to adapt to new technologies by scrapping the conventional methods. Indeed, technology is not mature enough yet in Malaysia to say that Malaysia in terms of energy technology is at its best. There is a scope for improvement in RE technologies, energy-efficient (EE) technologies, and power generation. A new technology setup comes with a capital cost and the risk of failing, but it can reduce the cost-per-unit of energy once it is established.

In Malaysia, investors are not too keen to invest in new technologies as there is a risk of failure and therefore, losing money and investment. ST2 has mentioned that it is better to wait until technology matures enough before using it, to avoid the risk of losing investment if these technologies fail. On the contrary, ST4 has said that Malaysia has evolved technology but needs to look forward to more green technology. ST9 suggests that ride e-hailing can be improved in Malaysia. This is where people from the same neighbourhood or locality can share rides to workplaces to reduce their carbon footprint. Adopting new technology would create a circular economy around it by creating jobs and boosting the national economy. Malaysia has an abundance of natural resources; therefore, there is not as much effort and room for novel technologies as discussed before as it comes with a cost of failing. Technology in Malaysia has improved PV cell efficiency of roughly $11 \%$ to $20 \%$ [53] now and change of coal plants from sub-critical to super-critical boilers according to ST14. Tenaga Nasional Berhad (TNB), the utility operator, benefits consumers by saving electricity in Malaysia.

Photovoltaic (PV) plants in Malaysia have developed over the years, and it is amongst one of the most developed technologies in Malaysia, and EE technologies are fast-growing. The government can look to have a higher share of EE technologies and work toward green buildings. Technological advancement has no boundaries, and there is always a scope to improve, now it is for the government to decide what they want to adopt at what scale that will benefit the nation to become more energy-efficient and at the same time cost-effective. 


\subsubsection{The 4 A's Dimensions of Energy Security}

\section{Affordability:}

Out of the $4 \mathrm{~A}^{\prime} \mathrm{s}$, most emphasis is given to affordability of energy alongside the availability of enough resources to make sure the living is sustainable. Affordability refers mainly to the energy price in terms of energy tariff and electricity tariff for different sectors in Malaysia or simply the equitable prices for people of all income groups. One of the most common demands of the community in a developing economy is to have affordable energy and a stable supply. Sometimes, these two do not go hand in hand as ensuring a stable supply of energy can be costly in a developing economy, yet the effort of the Malaysian government to provide energy price is low, and the supply is stable with a high reserve margin. Coal is not a clean source of energy, yet the cheapest source of energy, followed by natural gas and then RE. It is at the government's stake to decide how much they want to compensate for getting lower energy prices and their future strategies towards maintaining the same price yet reducing environmental impact.

Green energy and renewable energy are not the cheapest options of fuel in Malaysia, and the pricing of RE is not competitive with coal, but it may compete with that of natural gas per unit. This means Malaysia cannot increase its RE share to a large extent all at once because it will impair affordability and lead to consumer dissatisfaction. For electricity, the tariff is subsidised by the government and the same for fuels to some extent. The prices do not reflect the accurate market price as they would not be considered affordable and would lead to consumer dissatisfaction. Whenever there is a surplus in the fund, the money goes into the stabilisation fund for electricity, and these surpluses are used to compensate for when there is an increase in the original market price so that the consumers do not feel the impact of this increase. There are laws and regulations to ensure that the utility operator makes the supply secure and cost-effective.

Contrary to this, one of the stakeholders believes that the price should reflect the original market so that people do not waste energy. It is unfair for the poor and rich to have similar subsidies on fuel and electricity as the rich can afford more and at the same time waste more energy. There can be specific regulations that can ensure that the subsidy for electricity is at least based on income amongst the population to provide more equity. The electricity tariff is kept competitive with neighbouring countries like Thailand and Singapore to attract international business investors within the Malaysian grid. Global supply of energy does decide to some extent the price and availability of energy for importdependent countries. Malaysia has energy reserves to sustain itself, but they are also a net exporter of gas and oil and importer of all the coal used. Coal has a share of $60 \%$ in the energy mix of TPES, and roughly all is imported; hence, there is a risk of price volatility if the countries from where coal is imported decide to increase the price. This will affect the affordability dimension of ES in Malaysia.

\section{Accessibility:}

Accessibility is one of the dimensions that we do not worry about but still holds a key role because there is no point in having a continuous supply of energy at an affordable price if people do not have continuous access to it. Access to energy in urban areas does not pose much of a threat in rural and remote areas. Delivering energy there without disruption and much resilience is a challenge for the utility operators and the government. By right, every person in the nation has equal rights to the accessibility of energy resources. In Malaysia, accessibility is not much of an issue as it can be in some parts of the Philippines, as stated by ST10. According to ST10, equity and access are very much interrelated as there is no equity if everyone in the population does not have equal access to energy.

In the Philippines, there is a disparity between energy access between rural and urban areas. In recent days, delivering energy to all parts of the nation is not a challenge as it was probably 20 years ago. ST5 mentions that we have to look at the distributed energy, RE, and technical aspects when discussing accessibility. According to ST3, there is no point in having energy resources in the form of natural resource reserves if the technology of extracting them has not matured enough. Immature technology will not help in the cause 
of full exploration of the resources available and hence this will lead to poor accessibility of the energy sources. Overall, the stakeholders believe that the accessibility of energy in Malaysia is not worrying, so not many have spoken much about it, which proves that there is good access to energy in all parts of Malaysia.

\section{Acceptability:}

Acceptability of energy is at the disposal of the people and to some extent the government. It is most essential to ensure that the energy resources within the TPES and electricity generation are acceptable amongst the majority of the population to ensure their satisfaction. Nuclear energy is one of the most debatable sources of energy despite being the cleanest of them all and long-lasting, according to ST3. The recent accidents with nuclear reactors have given it a bad image and perception amongst the population therefore, they will not accept it despite its benefits and advantages over traditional power plants. This is where the government plays a role and decides whether they want to go with nuclear by making their population unhappy or stick to coal, oil, and gas as the primary sources.

ST7 believes that research institutes should take the lead role in designing and ensuring safe working conditions for nuclear plants in Malaysia, and by doing this, they can convince people and change their mindset on safety measures, also backed by Sen (2019) [67]. This is always a difficult choice for the government to make, and there are policies and laws in place for this. On the other hand, the acceptability of RE in Malaysia is relatively high amongst people, but the efficiency of RE as a source of power generation is not the most efficient of them all and comes with additional costs due to intermittency challenges. To ensure a continuous supply of energy, mostly in power generation, thermal power plants will always be the key in Malaysia. This compensation comes with a cost, and hence RE is not the most efficient source, yet it is highly acceptable.

Acceptability of RE is also poor within the business that has invested in coal power plants and CCGT plants as they fear losing business. So, the dilemma will always remain when it comes to choosing between nuclear and RE as the next primary fuel for energy in Malaysia. In Singapore, new technologies are adopted faster, like smart metering for electricity and EV, but there are still a certain group of people in the community unaware of these advantages. To become more efficient, there is a need to educate people on the transition from traditional technology to modern technologies. The acceptability of new technologies is still not very high in the ASEAN region, according to ST10, and this can be improved. According to ST6, to tackle ES challenges, the technical solutions must be economically feasible and socially acceptable. These suggest that the acceptability dimension of ES plays a key role in deciding the fate of ES of Malaysia as well.

\section{Availability:}

Availability of abundant natural and renewable resources is what every country aims to serve their population and thrive in economic activities. Malaysia is not any different; all the stakeholders have prioritised having an abundance of resources at their disposal as one of the key dimensions amongst all the other ES dimensions. If energy is not available at all times, it will hamper economic growth and living conditions. Availability of energy resources means strong geopolitical connections between countries with whom Malaysia has a trade of natural resources and at the same time safeguarding the available domestic resources in the best possible way. This requires having policies like the national depletion policy to ensure fair usage of the available resources. This may come with using more fossils, yet this dimension is always kept in check to ensure there are no power outages or the market price of energy does not reach ceiling height. One of the key dimensions to control population motivation and happiness is the availability of resources, and the Malaysian government has managed to do so at all times successfully. This comes at the cost of sacrificing the environmental dimension in terms of higher usage of coal and gas that contributes to higher greenhouse gas (GHG) emissions.

In this case, the government is looking forward to alternate sources that will decide the fate of fossils in Malaysia and according to all the stakeholders. The share of fossil fuels 
will not reduce drastically anytime soon in Malaysia. Malaysia has around 40-42 years of reserves within its energy reserve domestically. ST8, like most stakeholders, feels that a good share of RE in the energy mix is essential, and Malaysia should look forward to that to ensure higher availability of resources. ST9 has suggested educating people on wasting less energy, which is a sustainable solution for the future. Tax on a higher carbon emission than a set level can also work as a penalty to ensure that fossil fuels are used wisely. There should be incentives for those wasting less. These initiatives have to come from the government of Malaysia to ensure supply security at all times while ensuring lower waste and higher efficiency of the resources.

\subsubsection{Environmental Sustainability}

Energy is the backbone of all the economic activities within a country, and all dimensions of life are supported by energy [68]. Singh et al., (2018) [69] have stated that equity of energy resources, energy security of existing resources, and environmental stewardship and sustainability form the energy trilemma that needs effective policy formulation to balance the three [56]. According to ST13, energy in Malaysia has much interaction between demand and supply-side and economy and environment. In a developing economy like Malaysia, the availability of energy (energy equity) for boosting economic growth is prioritised in the energy trilemma, equity, and environmental sustainability. Most stakeholders have discussed this and have agreed that environmental sustainability targets come last in Malaysia, and economic growth takes priority.

ST4 mentions that the aim is towards economic ascendency in a developing economy rather than environmental ascendency. It is more important to ensure we have enough savings and a good lifestyle rather than thinking about climate change. ST8 believes that the impact of ES on the environment must be addressed with importance to avoid future generations from suffering from climate change adversities. This is quite rightly said, and there is a need to address depleting natural resources and carbon-based emissions due to the conventional power plants. There is a need to move towards greener energy sources that are less polluting and have a lower impact on climate change. The Malaysian government aims to be a greener economy and has small-scale plans to mitigate climate change challenges in its energy policies. ST14 believes that we are deciding between the trade-offs of affordability and the amount of environment we want; whether to rely on coal or cut down coal and increase RE share within TPES and electricity generation.

Malaysia aims to increase RE capacity by $20 \%$ in the energy mix for power generation by 2025. Currently, they sit at a 9\% share of RE in electricity generation, but this needs to be increased and a subsequent reduction in conventional plants to reduce pollution and reach the $\mathrm{CO}_{2}$ emission targets. There is a scope of improvement in more energyefficient technologies that support cars and buildings. The number of electric vehicles in Malaysia in public transport and private vehicles can be increased while the office buildings and residential buildings can be turned into more energy-efficient ones by adopting new technologies. Overall, there needs to be a lot of emphases given on this dimension of ES as it indicates a clear picture of the status of a country's ES. Having energy at all times with affordable rates is important that should not come at the expense of comprising the nation's environmental health, by having higher availability of energy and low tariffs. This does improve ES, but at the same time, higher carbon-based emissions will reduce the long-term ES of the country. Hence, equal importance should be attached to these dimensions as well.

\subsubsection{Economic Development}

Economic development is given one of the most critical priorities in any developing economy. Malaysia as a nation is heading towards a high-income country status with an economic growth rate of 5.4\% from the year 2010. In Malaysia, economic development will be given more priority than any other dimension of ES. When we look into the energy trilemma, energy equity comes first, and environmental sustainability comes last for most studies. According to all the stakeholders in this study, the Malaysian government will 
attach the most importance to economic growth while prioritising the activities that affect the environment and contribute to climate change. This means conventional thermal power plants of coal and CCGT plants will remain to power Malaysia for a very long time in the future as well. These power plants, compared to RE plants, are more efficient and cost-effective. They are cheaper to operate and hence reduce the cost per $\mathrm{KW} \mathrm{h}$. RE projects in Malaysia are looked upon as an opportunity to invest in new businesses according to ST4 rather than to mitigate climate change challenges. Not just that, they also create job opportunities, hence boosting the economy.

According to ST2, downstream activities in Terengganu have given employment, infrastructural development, and the ability to trade these resources with the rest of the world. This leads to the development of the local economy, employment for locals, and also improvement in education and living standards in these areas. ST3 suggests that Malaysia has enough resources to sustain economic activities, and there is good income on fossil fuel export and stable fossil fuel supply that means the country has a good subsidy on fossil fuels. Addressing ES challenges have to be feasible, economically viable, and socially acceptable according to ST6. There are a lot of opportunities for investment in terms of RE in Malaysia that will boost the Malaysian economy as more business opportunities bring in more tax which increases the national gross domestic product (GDP). The trade and finance industry looks at RE as a new business opportunity and not just for climate change matters.

Malaysia is also a net exporter of oil and gas. They export high-quality oil and gas in return for lower-grade oil and gas for a positive trade-off. This benefits the economic growth of the nation. Trading in these current times is a crucial aspect to maintain geopolitical relations as well. There is a positive net gain in this trade, strengthening the vital trade relationship between countries. In the ASEAN region, there are certain agreements of trade to help out each other in the region. According to ST14, if the trade brings economic benefit and helps the region bond stronger by helping each other, it is healthy for the nation.

\subsubsection{The Role of Governance}

The governance of the energy resources is completely in the hand of the ruling government and its relevant ministries. Hence, they are at the forefront of decision-making in terms of policy setting, laws, regulations, and legislation on the energy-related matters of the nation. Whether they have the vision and aim to have high ES will decide what kind of energy policies they will set and what kind of depletion policies the government will set for natural resources. These policies are monitored and regulated by the government agencies like SEDA and the Energy commission. In Malaysia, the government holds the highest authority in this decision-making and aims to become a green economy. Hence, the policies should reflect their aim as well. The government's decision to transition to green energy will impact the long-term ES of the nation.

To achieve long-term ES, it is essential to have clean energy sources that are sustainable and environmentally friendly. At this point, in Malaysia, the key priority is towards the high availability of energy and at an affordable rate. This comes with the compromise of clean energy, as clean energy is not cheaper than coal or natural gas. Hence, prioritising the need, Malaysia is still not looking towards a transition phase to alternate fuel sources as of yet as it can impair affordability and thus lead to consumer dissatisfaction. The decision of new powerplants, how much capacity is to be increased, and how to replace the ageing plants with new ones lies at the government's disposal. All these decisions, in turn, do have an impact on the ES of the nation. More significant economies and countries like China need to take these bold steps first, as their contribution towards climate change can be more impactful than smaller developing economies like Malaysia. According to ST4, Malaysia's contribution to climate change is minimal compared to the bigger players, and hence Malaysia should not be highly concerned and instead focus on the nation's economic growth. 
The government of Malaysia also feels the same way, and they have provided opportunities for RE businesses to grow and gradually be more considerable in numbers and scale. This creates jobs, boosts the economy, and improves living conditions, mostly in rural areas. An entirely circular economy can grow around large power plants and power projects, mostly in areas where the living standards have a chance to improve. According to most stakeholders, there is government intervention in the vertical electricity market, and there is a scope to slowly move towards a more horizontal free market. Singapore has adopted the free market structure. There are advantages and disadvantages to both; in a free market, the price does not stay within the control of the government. Hence, they cannot intervene much if there is a sudden hike in prices; the community will feel the burden of rising prices. In Malaysia, the natural gas market is moving towards a more accessible market approach, but electricity remains vertical and monopolised.

Nuclear energy is one of the most debatable sources of clean energy. Nuclear energy has various advantages of being long-lasting, lower cost, and cleaner form of energy but has the stigma of being unsafe due to the reactor accidents in the recent past, according to ST3 and 15. The government will play a vital role in deciding when nuclear energy can be introduced or whether there will be any nuclear energy at all. The public acceptability will always be very low due to the risks attached, and the government trying to champion this technology will face backlash from their supporters and the population. This will always be a tricky topic and challenge for the Malaysian government. Most of the decisions that seal the fate of the ES of Malaysia lie within the hands of the government and their vision of how they see the ES of the nation. The policies towards alternative fuel usage in Malaysia are still not very well defined, and it requires additional research for different RE sources, such as biomass-based biofuels, solar power, small and large hydropower, and wind. Some studies do life cycle assessments and feasibility studies for RE projects; however, the implementation of these studies needs to be improved for further success of alternative fuel sources.

\subsection{Implementation of the Securitisation Framework}

The development of the securitisation framework has been discussed in detail in Section "Exploring the Concept of Securitisation of Energy through Copenhagen School Theory", and the implementation of the framework and the results are discussed further in this section. The framework can be broken down into the following components: (1) Securitising actor, (2) Speech Act, (3) Existential Threat, (4) Extraordinary Measures, (5) Urgency and (6) Referent Object $[34,36,70]$. Figure 5 below shows the implementation of the framework based on the results obtained from this study in Sections 3.1 and 3.2. However, the framework has been critiqued over time, and different research groups have suggested changes and expressed their opinions.

The studies of McDonald (2008) [71], Balzacq (2005) [72] and Stritzel (2007) [73] has stated that the Copenhagen School's expanded security objective and their approach to securitisation has been challenged as being too restricted, too concentrated on the speaking acts, and hence unsuitable for the analysis of real-world circumstances. Various academics have, therefore, advocated for more attention to multiple elements to broaden the notion beyond the speech act (or securitising action), making it more accessible to empirical study and better equipped to explain "the emergence of specific security concerns" [74].

In this framework, the following have been identified as the most suitable representation for each of the components.

$>$ Securitising actors: The ministry of energy, energy commission of Malaysia, SEDA and other regulatory bodies that are directly in charge of the decision making of the energy policies of Malaysia.

$>$ Referent objects: The dimensions and the themes of ES discussed in Section 3.2 can be classified into this category. However, not all the indicators within these dimensions are a part of this cluster, e.g., energy availability, energy price and affordability, the 
depletion of natural resources are some of the key referent objects that are existentially threatened and has the chance of regrouping and survival.

$>$ Once the securitising actor has succeeded in convincing the relevant stakeholders engaged in this study and the essential bodies that a referent object is existentially threatened, they can proceed to the next stage. Only then can extraordinary measures be disposed of. This is followed by identifying the speech act.

$>$ Speech Act: In this case, the speech act is the gap in ES policy within Malaysia's energy policy structure. It is the discursive representation of the issue that can be identified as an existential threat to ES.

In the successful act of securitisation, the governments and political elites will have the edge over other players in attempting to influence audiences and pushing for the execution of exceptional measures if securitisation is effective. The audience in democratic nations still has the right to reject the speech act-the portrayal of a particular problem as an existential threat. In the case of Malaysia, the role of government plays is very well defined in taking extraordinary measures to tackle the existential threat to the ES of the nation.

\subsection{Indicator Mapping Process}

The selection of the most suitable dimensions for a quantitative assessment of the ES of Malaysia can be made from the seven themes that have been thoroughly discussed in this study. It is important to understand the dimension from the stakeholders' perspective to avoid bias in dimension selection. Herie et al., (2021) [75] has stated the importance of quantitative assessment of energy supply security to ensure viable strategies against poor ES performance can be made. A lack of robustness in discussing the selection of dimensions has been noticed in Malaysia's ES literature. The sample dimensional indicator mapping process has been shown in Table 6 for the Availability dimension only. The indicators have been selected from 18 studies that have worked on the development of the energy security index for a country or a region within Asia. This is proposed to be a more robust way to select indicators after selecting the right dimensions through the proposed method in this study.

This overall research is a mix of qualitative and quantitative approaches. This current manuscript focuses on the qualitative aspects in terms of data collection, analysis and discussion. However, the future scope of the recent research is to quantify every shortlisted indicator from the mapping process in Table 6 to develop an energy security index (ESI) for Malaysia, and the same framework would apply to countries with a similar energy outlook.

Table 7 consists of quantitative data of the selected indicators for the availability dimension. A similar process would be replicated for the future scope of the overall quantitative assessment of ES to develop the ESI. All the selected themes and their dimensions will be quantified in the same way. 
Table 6. Indicator Mapping of Availability dimension.

\begin{tabular}{|c|c|c|c|c|c|c|c|c|c|c|c|c|c|c|c|c|c|c|c|c|}
\hline Indicators & $\underset{\mathbb{N}}{\mathbb{J}}$ & త్ర & 氖 & $\begin{array}{l}\Xi \\
\unrhd\end{array}$ & $\underline{\infty}$ & 太 & $\begin{array}{l}\bar{\infty} \\
\stackrel{\Delta}{\Delta}\end{array}$ & $\bar{\Xi}$ & $\begin{array}{l}\bar{\sigma} \\
\stackrel{\infty}{0}\end{array}$ & $\vec{\nabla}$ & $\begin{array}{l}\widetilde{N} \\
\infty\end{array}$ & $\stackrel{\mathscr{\infty}}{\infty}$ & $\underset{\Phi}{F}$ & $\begin{array}{l}\overline{0} \\
\infty \\
15 \\
\infty \\
\infty\end{array}$ & $\underset{\infty}{\mathbb{\infty}}$ & $\begin{array}{l}\infty \\
\stackrel{\infty}{\infty}\end{array}$ & $\underset{\infty}{\bar{\infty}}$ & 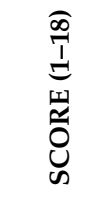 & & 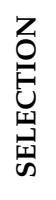 \\
\hline Total Primary energy supply per capita (TPES/pop) & & $\checkmark$ & $\checkmark$ & & & & & $\checkmark$ & $\checkmark$ & $\checkmark$ & & & & $\checkmark$ & & & & 6 & Yes & \\
\hline Electrification level & & & $\checkmark$ & & & & & & $\checkmark$ & & & & & & & & & 2 & & \\
\hline Net-import to consumption ratios (all energy sources) & & & $\checkmark$ & & & & & & & & & & & & & & $\checkmark$ & 2 & & \\
\hline $\mathrm{R} / \mathrm{P}$ of natural gas & $\checkmark$ & $\boldsymbol{v}$ & & & $\boldsymbol{v}$ & & & $\checkmark$ & $\checkmark$ & $\checkmark$ & $\checkmark$ & $\checkmark$ & & $\checkmark$ & $\checkmark$ & $\checkmark$ & & 11 & Yes & \\
\hline $\mathrm{R} / \mathrm{P}$ of coal & & & & & $\checkmark$ & & $\boldsymbol{v}$ & & $\boldsymbol{v}$ & $\checkmark$ & $\checkmark$ & $\checkmark$ & & $\checkmark$ & $\boldsymbol{v}$ & $\checkmark$ & & 9 & Yes & \\
\hline Coal import dependency ratio & $\checkmark$ & & & & & & & $\checkmark$ & & $\checkmark$ & & & $\checkmark$ & & & & & 4 & & \\
\hline Oil import dependency ratio & & & & & & & $\checkmark$ & $\checkmark$ & & $\checkmark$ & & & $\boldsymbol{V}$ & & & $\checkmark$ & & 5 & & \\
\hline Total primary energy supply over GDP (TPES/GDP) & & & & & & & & $\checkmark$ & & $\checkmark$ & & & & & & & & 2 & & \\
\hline Energy self-sufficiency ratio & & $\boldsymbol{V}$ & & $\boldsymbol{V}$ & & & & & & & $\boldsymbol{V}$ & $\checkmark$ & & $\boldsymbol{V}$ & $\checkmark$ & $\boldsymbol{v}$ & & 7 & Yes & \\
\hline Fossil fuel primary consumption & & & & $\boldsymbol{v}$ & & & & & & & & & & & & & & 1 & & \\
\hline Share of imports in coal, oil, and gas supply (\%) & & & & & & $\boldsymbol{V}$ & & & & $\checkmark$ & & & & & & & & 2 & & \\
\hline Availability factor of conventional thermal electricity & & & & & & & $\boldsymbol{V}$ & & & & & & & & & & & 1 & & \\
\hline Availability factor of non-thermal electricity & & & & & & & $\checkmark$ & & & & & & & & & & & 1 & & \\
\hline Access to clean fuel (\%) & & & & & & & & $\checkmark$ & & & & & & & & & & 1 & & \\
\hline Final Energy Consumption Per capita (TFEC/pop) & & & & & & & & $\checkmark$ & $\checkmark$ & & & & $\checkmark$ & & $\checkmark$ & & $\checkmark$ & 5 & Yes & \\
\hline Resource Estimates or Reserves & & & & & & & & & & $\checkmark$ & & & $\boldsymbol{V}$ & & $\checkmark$ & & $\boldsymbol{V}$ & 4 & & \\
\hline Total primary energy production per capita (TPEP/pop) & & & & & & & & & & & $\checkmark$ & $\checkmark$ & & & & & & 2 & & \\
\hline TFEC/GDP & & & & & & & & & & & & & $\checkmark$ & & & & & 1 & & \\
\hline Fuel mix of TPES & & & & & & & & & & & & & $\checkmark$ & $\checkmark$ & & $\checkmark$ & & 3 & & \\
\hline Total Energy production/Total energy consumption & & & & & & & & & & & & & & & & & $\checkmark$ & 1 & & \\
\hline Diversification of energy supply & & & & & & & & & & & & & & & & & $\checkmark$ & 1 & & \\
\hline
\end{tabular}


Table 7. Quantitative data collection for availability dimension.

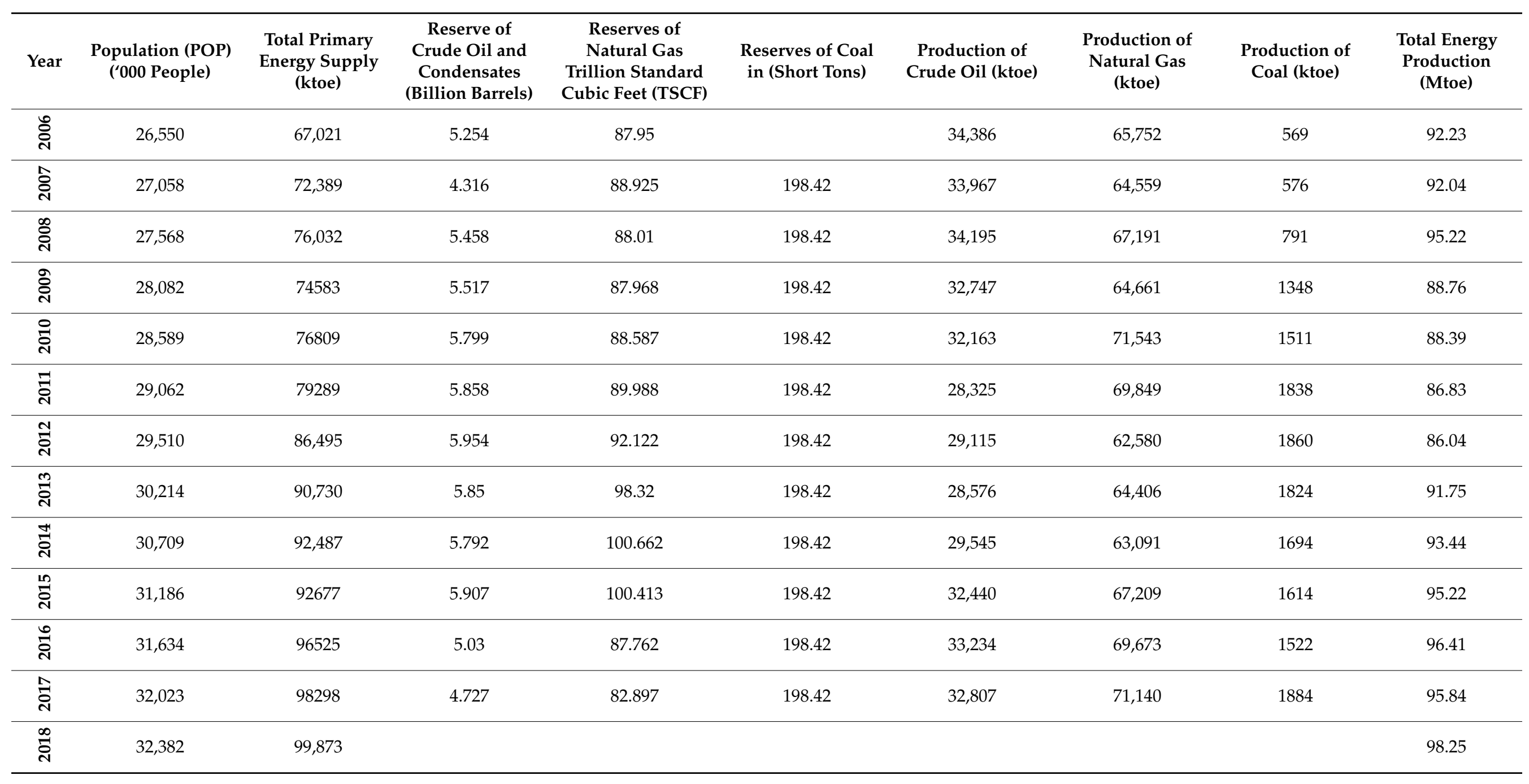




\section{Conclusions and Policy Implications}

The main contribution of this study is towards developing a consolidated knowledge of ES for Malaysia by studying emerging themes from SSIs with key stakeholders. The gap of stakeholder engagement to analyse ES dimensions and themes has been mentioned in the introduction section. Upon completion of this research, the seven themes that have emerged from the interviews are described in detail to understand the interaction between the energy policy structure of Malaysia and how it has an impact on the ES of Malaysia. It is recommended to conduct more research following the aforementioned methods because it is a robust way to deep-dive the ES challenges and mitigate them. There is a need for an ES policy within the energy policy framework of Malaysia to ensure that a single document lists down the challenges, the mitigation plan, and the outcome of these plans. Currently, there are mentions of ES in different policies, including green technology policy, renewable energy transition roadmap (RETR), and in a few energy supply policies that mention supply security of the resources.

\subsection{Energy Policy Implications}

The energy policies of a country decide how energy resources would be used efficiently, the trade of energy between countries, energy mix for different sectors, and many other factors that affect the ES of a country directly or indirectly. Similarly, Malaysia has its energy policies and acts in place by the government that is regulated and monitored by their regulatory and statutory bodies alongside the relevant ministries. The stakeholders have indicated that the Malaysian government makes the final call to set energy policy targets, like the RE penetration target of $31 \%$ for power generation by 2025 [20]. Others include the national depletion policy that limits the use of oil to merely 700,000 barrels/day which could otherwise be increased to 1 million barrels/day, but the policy does not allow it. Power purchase agreement (PPA) tackles the problems related to power plants and how different fuels are allocated for power plants and to what extent.

According to ST2, the policies should target specific issues; hence it calls for specific policies to address them. There should be incentive-based policy making so that incentives are given to those following them and penalise the ones not following according to ST6. Most stakeholders have said that energy policymaking should be evidence, fact, and science-based, where targets to be set must be realistic and achievable within a given time frame. To do so, the energy planners of the nation need to be well aware of the situation around them. This requires proper training and a lot of research to be carried out in the respective field.

In the end, the decision still lies in the hands of the government to whether accept or reject certain proposals from the policy setters. Historically in Malaysia, the RE projects have not fulfilled their ultimate targets within the given time, which raises questions for future RE policies. Despite that, according to all the stakeholders, there is a push for more $\mathrm{RE}$ in Malaysia. They want a higher share of RE in the energy mix for Malaysia as it can bring positive results for the ES of the nation. Increasing this will require proper planning and implementation of the policy; there need to be viable strategies to fulfil the targets set in the policy documents. SEDA was formed to take charge of RE policies and their regulation in Malaysia.

Large-scale solar (LSS) projects and Feed-in-tariff and net metering (NEM) are part of Malaysia's RE policies and aim to improve the sustainability of energy resources in Malaysia. Renewable energy transition roadmap (RETR) 2035 will develop strategies to reach the RE targets by 2035, which is set and regulated by SEDA. If we want more RE, then there is a need for more policies and roadmaps with a conducive environment for these investments to be made. ST8 has suggested having a policy that can enforce a tax on industries that emit carbon-based emissions above allowed limits. ST9 has suggested having an emergency response mechanism to any sort of challenge that Malaysia may face. This can be used during a pandemic situation like that of covid-19. 
The mitigation plans for energy issues and challenges are there in different departments and agencies, but they are not documented as a whole. Similarly, no energy security policy addresses the ES challenges and their mitigation plans. There can be a single policy document to mitigate any immediate or long-term ES challenge for Malaysia. Nupueng et al., (2018) [72] have mentioned the need for stable and consistent policies addressing these issues to ensure the successful outcome of the objectives. Energy wastage needs by industries or households need to be monitored regularly Aziz et al., (2020) [73]. There can be a policy in place that looks after this, and hence it will impact the energy availability dimension of ES. ST13 believes that in Malaysia, there needs to have better synchronisation between the agencies and ministries to make sure the responsibilities are distributed evenly to ensure work efficiency.

ST14 mentions a few other policies like the Malaysian national energy policy 20212040, natural gas roadmap, and action plan 2021-2025 drafted to tackle future challenges. All three coupled with RETR talks about RE and energy for Malaysia. ST15 says that demand and supply are mainly considered during policy setting, and security issues are not given much importance. However, this should be changed, and more security issues like ES must be considered. ST16 mentioned that we should make policies for long-term solutions and set long-term goals instead of short-term quick fixes; $2-3$ years is a short time for any objective within the energy policies. Policies need to be well planned with proper targets set with sufficient time given to ensure they effectively achieve targets.

\subsection{Recommendations from Malaysia's Context}

There are key selective takeaways from this research that have been listed down for achieving higher ES status and sustainable development in Malaysia.

i. The increase in the share of RE in the TPES and power generation will be the key in deciding whether there will be a reduction in the dependency on fossil fuels as the only form of energy source.

ii. The successful implementation of the objectives mentioned in the policy documents, including the most recent "REPORT ON PENINSULAR MALAYSIA GENERATION DEVELOPMENT PLAN 2020 (2021-2039)" by Energy Commission Malaysia, (2020) will be vital towards shaping a sustainable future for Malaysia. Most of the energy policies in place need to achieve their targets at the same time to make sure that ES challenges are mitigated.

iii. Environmental sustainability needs to be at the forefront of the energy trilemma if ES is to be improved.

iv. The ESI needs to be developed following the indicator mapping process explained in Section 3.4 and the dimension selection process from the emerging themes to ensure that the term ES can be quantified to reflect upon the overall performance over a period.

v. A combination of qualitative (stakeholder engagement and survey) and quantitative (ESI development) analysis needs to be carried out in parallel to ensure that the data generated are validated throughout the process. A futuristic approach of system dynamic modelling of the dimensions and different ES scenarios can also be studied, as carried out by S. Shadman et al., (2021) [16] to develop a causal relationship between indicators and dimensions.

vi. An overall gap assessment is recommended for the current body of work on ES for Malaysia. This assessment requires a collaborative effort between stakeholders who are in the decision-making position for ES policies with ES researchers to create a framework that involves both qualitative and quantitative assessment of ES. The current gap has been identified to be the depth of research and engagement with experts to identify the dimensions of ES, which this research has tried to fulfil successfully and with depth in research and the methods.

These recommendations can be implemented to ensure that the concept of ES of Malaysia is defined in-depth with a strong data-driven and evidence-based approach. 
This research provides the flexibility of implementation within any country with a similar energy outlook to establish an ESI by selecting the ideal dimensions and indicators of ES.

\subsection{Recommendations from a Global Context}

A similar set of recommendations are applicable to countries with the same pattern for energy demand, energy consumption and energy policy structures. Countries with heavy dependency on fossils fuels that are available within as reserves would require policies, such as "Depletion policy" or anything similar that can limit the use of fossils per year from the reserves. This would improve the reserves to production ratio $(R / P)$ of the fossil fuels hence improving the long-term availability of these sources at the same time lowering GHG emissions and hence climate change impact. On the other hand, countries dependent on energy import needs to look for alternative sources within their geographical location to ensure that a future cut or reduction in import would not hamper the accessibility of energy within the country. Improved research and development of energy-efficient technologies for renewable energy generation and distribution would hold the key in this case.

Environmental degradation policies need to be strengthened based on regional meets and global agreements, such as the Paris Agreement and Kyoto protocol. However, the implementation of these protocols and agreed mitigation measures and emission levels need to be improved to ensure the targets are achieved. An improvement in tracking the progress of the countries bound by these agreements needs to be set up for better implementation and monitoring purposes. Overall, it can be concluded that each of these seven themes conceptualise ES in a consolidated manner with causation and relation between indicators from each theme and dimension. This further proves the multi-dimensional nature of ES and the need to develop these themes and dimensions further for quantification of these dimensions with greater accuracy, completeness and transparency.

Author Contributions: Conceptualisation, S.S. and C.M.M.C.; Methodology, S.S., C.M.M.C., E.H.Y.; Software, S.S.; Validation, M.M.H. and N.S.; Formal Analysis, S.S., C.M.M.C., M.M.H., N.S., E.H.Y.; Data Curation, S.S.; Writing-Original Draft Preparation, S.S.; Writing-Review \& Editing, C.M.M.C., M.M.H.; Visualization, E.H.Y.; Supervision, C.M.M.C., E.H.Y., N.S.; Funding Acquisition, M.M.H. All authors have read and agreed to the published version of the manuscript.

Funding: This research has received a grant from the National University of Malaysia (GUP-2020-034 and DIP-2019-001).

Institutional Review Board Statement: The research approval has been granted by the Science \& Engineering Research Ethics Committee under the reference of; SEREC Reference: SS160420.

Data Availability Statement: The data that support the findings of this study are available upon request.

Acknowledgments: The authors would like to thank the 16 stakeholders' participants of the SSIs and the 117 survey participants for actively taking part in the data collection process of this research.

Conflicts of Interest: There is no conflict of interest between the authors to declare.

\footnotetext{
Abbreviations

ES-Energy security; GHG—Greenhouse gas; SEDA—Sustainable Energy Development Authority; SSI-Semi-Structured Interview; GT-Grounded Theory; R/P-Reserve to production ratio; TPESTotal Primary Energy Supply; TFEC - Total Final Energy Consumption; GDP—Gross Domestic Product; TPEC - Total Primary Energy Consumption; $\mathrm{CO}_{2}$ - Carbon dioxide; RE-Renewable Energy; ESI-Energy Security Index; RETR—Renewable Energy Transition Roadmap; ST—Stakeholder; CCGT_Combined Cycle Gas Turbines.
} 


\section{Appendix A}

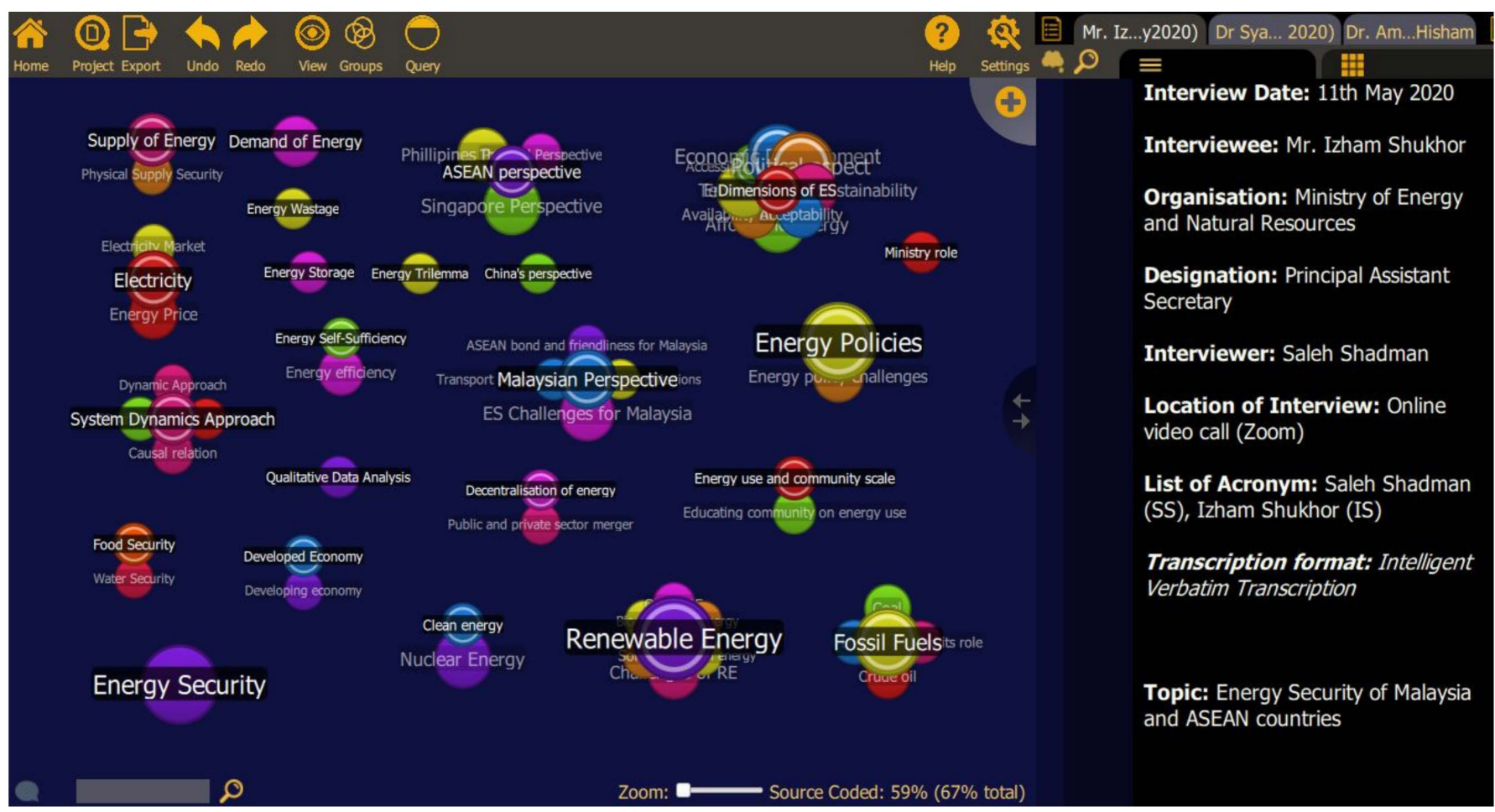

Figure A1. Overall Quirkos Dashboard of this project.

\section{References}

1. Dincer, I.; Rosen, M.A. A worldwide perspective on energy, environment and sustainable development. Int. J. Energy Res. 1998, 22, 1305-1321. [CrossRef]

2. Kumar, D.; Tewary, T. Techno-economic assessment and optimization of a standalone residential hybrid energy system for sustainable energy utilization. Int. J. Energy Res. 2021. [CrossRef]

3. Lee, K.E.; Mokhtar, M.; Mohd Hanafiah, M.; Abdul Halim, A.; Badusah, J. Rainwater harvesting as an alternative water resource in Malaysia: Potential, policies and development. J. Clean. Prod. 2016, 126, 218-222. [CrossRef]

4. Ashari, H. Energy Security, Energy Efficiency, and Energy Dialogue; Parliment of Malaysia: Kuala Lumpur, Malaysia, $2013 ;$ p. 26.

5. Winzer, C. Conceptualizing Energy Security. Energy Policy 2012, 46, 36-48. [CrossRef]

6. Azzuni, A.; Breyer, C. Definitions and dimensions of energy security: A literature review. Wiley Interdiscip. Rev. Energy Environ. 2018, 7, 1-34. [CrossRef]

7. Shepard, J.U.; Pratson, L.F. Hybrid input-output analysis of embodied energy security. Appl. Energy 2020, 279, 115806. [CrossRef] [PubMed]

8. Tongsopit, S.; Kittner, N.; Chang, Y.; Aksornkij, A.; Wangjiraniran, W. Energy security in ASEAN: A quantitative approach for sustainable energy policy. Energy Policy 2016, 90, 60-72. [CrossRef]

9. Kucharski, J.; Unesaki, H. A Policy-oriented Approach to Energy Security. Procedia Environ. Sci. 2015, 28, 27-36. [CrossRef]

10. Kamyk, J.; Kot-Niewiadomska, A.; Galos, K. The criticality of crude oil for energy security: A case of Poland. Energy 2021, $220,119707$. [CrossRef]

11. Nair, K.; Shadman, S.; Chin, C.M.M.; Sakundarini, N.; Hwa Yap, E.; Koyande, A. Developing a system dynamics model to study the impact of renewable energy in the short- and long-term energy security. Mater. Sci. Energy Technol. 2021. [CrossRef]

12. Dincer, I.; Acar, C. A review on clean energy solutions for better sustainability. Int. J. Energy Res. 2015, 39, 585-606. [CrossRef]

13. Safari, A.; Das, N.; Langhelle, O.; Roy, J.; Assadi, M. Natural gas: A transition fuel for sustainable energy system transformation? Energy Sci. Eng. 2019, 7, 1075-1094. [CrossRef]

14. Zakaria, Z.; Kamarudin, S.K.; Wahid, K.A.A. Fuel cells as an advanced alternative energy source for the residential sector applications in Malaysia. Int. J. Energy Res. 2020, 45, 1-26. [CrossRef]

15. Hosseini, S.E.; Abdul Wahid, M. The role of renewable and sustainable energy in the energy mix of Malaysia: A review. Int. J. Energy Res. 2014, 38, 1769-1792. [CrossRef]

16. Ludin, N.A.; Mustafa, N.I.; Hanafiah, M.M.; Ibrahim, M.A.; Asri Mat Teridi, M.; Sepeai, S.; Zaharim, A.; Sopian, K. Prospects of life cycle assessment of renewable energy from solar photovoltaic technologies: A review. Renew. Sustain. Energy Rev. 2018, 96, 11-28. [CrossRef] 
17. Shadman, S.; Chin, C.M.M.; Sakundarini, N.; Yap, E.H. Quantifying the Impact of Energy Shortage on Malaysia's Energy Security Using a System Dynamics Approach; Springer: Singapore, 2021; pp. 143-154.

18. Dharfizi, A.D.H.; Ghani, A.B.A.; Islam, R. Evaluating Malaysia's fuel diversification strategies 1981-2016. Energy Policy 2020, $137,111083$. [CrossRef]

19. Lim, Z.W.; Goh, K.L. Natural gas industry transformation in Peninsular Malaysia: The journey towards a liberalised market. Energy Policy 2019, 128, 197-211. [CrossRef]

20. Energy Commission Malaysia Report on Peninsular Generation Development Plan 2019; Energy Commission of Malaysia: Putrajaya, Malaysia, 2020; Volume 2019, p. 10.

21. Yergin, D. Ensuring Energy Security. Foreign Aff. 2006, 85, 69. [CrossRef]

22. Krupa, J. The Quest: Energy, Security, and the Remaking of the Modern World. AAG Rev. Books 2014, 2, 60-62. [CrossRef]

23. Gasser, P. A review on energy security indices to compare country performances. Energy Policy 2020, 139, 111339. [CrossRef]

24. Sahid, E.J.M. Energy security in Malaysia: A quantitative analysis. Int. J. Eng. Technol. 2018, 7, 400-403. [CrossRef]

25. Sahid, E.J.M.; Siang, C.C.; Peng, L.Y. IOP Conference Series: Earth and Environmental Science Enhancing energy security in Malayia: The challenges towards sustainable environment Enhancing energy security in Malayia: The challenges towards sustainable environment. IOP Conf. Ser. Earth Environ. Sci 2013, 16, 12120. [CrossRef]

26. Yusoff, N.Y.M.; Bekhet, H.A. Developing and evaluating the sustainable energy security index and its performance in Malaysia. Int. J. Energy Econ. Policy 2020, 10, 444-455. [CrossRef]

27. Sharifuddin, S. Methodology for quantitatively assessing the energy security of malaysia and other southeast asian countries. Energy Policy 2014, 65, 574-582. [CrossRef]

28. Foo, K.Y. A vision on the opportunities, policies and coping strategies for the energy security and green energy development in Malaysia. Renew. Sustain. Energy Rev. 2015, 51, 1477-1498. [CrossRef]

29. Khattak, M.A.; Lee, J.K.; Khairul, A.B.; Tan, X.H.; Amirul Syafiq, O.; Afiq Danial, A.R.; Lailatul Fitriyah, A.S.; Kazi, S. Global Energy Security and Malaysian Perspective: A Review. Prog. Energy Environ. 2018, 6, 1-18.

30. Shadman, S.; Chin, C.M.M. The role of current and future renewable energy policies in fortifying Malaysia' s energy security: PESTLE and SWOT analysis through stakeholder engagement. Prog. Energy Environ. 2021, 16, 1-17.

31. Securitization and State Encroachment on the Energy Sector: Politics of Exception in Poland's Energy Governance-Science Direct. Available online: https:/ /www.sciencedirect.com/science/article/pii/S0301421519306536?via\%3Dihub\#bib67 (accessed on 14 October 2021).

32. Szulecki, K. Securitization and state encroachment on the energy sector: Politics of exception in Poland's energy governance. Energy Policy 2020, 136, 111066. [CrossRef]

33. Wæver, O. Politics, security, theory. Secur. Dialogue 2011, 42, 465-480. [CrossRef]

34. Stritzel, H. (Ed.) Securitization Theory and the Copenhagen School BT-Security in Translation: Securitization Theory and the Localization of Threat; Palgrave Macmillan: London, UK, 2014; pp. 11-37; ISBN 978-1-137-30757-6.

35. Emmers, R. Securitization. In Contemporary Security Studies; Oxford University Press: Oxford, UK, 2015.

36. Özcan, S. Securitization of Energy through the Lenses of Copenhagen School. West East J. Soc. Sci. 2013, 2, 57-72.

37. Shadman, S.; Chin, C.M.M.; Sakundarini, N.; Yap, E.H.; Velautham, S. Methodological Review of Malaysia's Energy Security Measurement: A Systems Approach using Stakeholder Engagement. IOP Conf. Ser. Mater. Sci. Eng. 2021, 1092, 012032. [CrossRef]

38. Sovacool, B.K.; Drupady, I.M. Examining the small renewable energy power (SREP) program in Malaysia. Energy Policy 2011, 39, 7244-7256. [CrossRef]

39. Mouraviev, N. Energy security in Kazakhstan: The consumers' perspective. Energy Policy 2021, 155, 112343. [CrossRef]

40. Fusch, P.I.; Ness, L.R. Are we there yet? Data saturation in qualitative research. Qual. Rep. 2015, 20, $1408-1416$.

41. Lillis, A.M. A framework for the analysis of interview data from multiple field research sites. Account. Financ. 1999, 39, 79-105. [CrossRef]

42. Turner, D.W. Qualitative interview design: A practical guide for novice investigators. Qual. Rep. 2010, 15, 754-760.

43. Charmaz, K. Introducing qualitative methods. In Constructing Grounded Theory, 2nd ed.; Sage: London, UK, 2014; ISBN 9780857029133.

44. Zhu, P.; Luke, M.; Bellini, J. A Grounded Theory Analysis of Cultural Humility in Counseling and Counselor Education. Couns. Educ. Superv. 2021, 60, 73-89. [CrossRef]

45. Charmaz, K. Grounded Theory in Global Perspective: Reviews by International Researchers. Qual. Inq. 2014, 20 , 1074-1084. [CrossRef]

46. Chun Tie, Y.; Birks, M.; Francis, K. Grounded theory research: A design framework for novice researchers. SAGE Open Med. 2019, 7. [CrossRef] [PubMed]

47. Hesse-Biber, S.N.; Leavy, P. Approaches to Qualitative Research: A Reader on Theory and Practice; Hesse-Biber, S.N., Leavy, P., Eds.; Oxford University Press: Oxford, UK, 2004; ISBN 0195157753.

48. Energy Comission Malaysia Malaysia Energy Statistics Handbook. Available online: https://www.st.gov.my/en/contents/files/ download/116/Malaysia_Energy_Statistics_Handbook_20201.pdf (accessed on 1 October 2021).

49. Looney, B. Statistical Review of World Energy globally consistent data on world energy markets. and authoritative publications in the field of energy. Rev. World Energy Data 2021, 70, 8-20. 
50. Zulkifli, Z. Malaysia Country Report. In Proceedings of the 17 th AsiaConstruct Conference; 2021; pp. 170-190. Available online: https: / / www.google.com.hk/url?sa=t\&rct=j\&q=\&esrc=s\&source=web\&cd=\&cad=rja\&uact=8\&ved=2ahUKEwiOg8CVvzzAhWsF6YKHUsfBOgQFnoECBAQAQ\&url=https\%3A\%2F\%2Fwww.eria.org\%2Fuploads\%2Fmedia\%2FBooks\%2F2021Energy-Outlook-and-Saving-Potential-East-Asia-2020\%2F18_Ch.11-Malaysia.pdf\&usg=AOvVaw02r9wDaB8c0Uz1nQxv2GPx (accessed on 20 October 2021).

51. Journal, I. Skype interviewing: The new generation of online synchronous interview in qualitative research. Qual. Res. 2014, 1, 9-11. [CrossRef]

52. Acar, C. A comprehensive evaluation of energy storage options for better sustainability. Int. J. Energy Res. 2018, 42, 3732-3746. [CrossRef]

53. Kaya, F.; Şahin, G.; Alma, M.H. Investigation effects of environmental and operating factors on PV panel efficiency using by multivariate linear regression. Int. J. Energy Res. 2021, 45, 554-567. [CrossRef]

54. Olatomiwa, L.; Mekhilef, S.; Huda, A.S.N.; Sanusi, K. Techno-economic analysis of hybrid PV-diesel-battery and PV-winddiesel-battery power systems for mobile BTS: The way forward for rural development. Energy Sci. Eng. 2015, 3, $271-285$. [CrossRef]

55. Vaka, M.; Walvekar, R.; Rasheed, A.K.; Khalid, M. A review on Malaysia's solar energy pathway towards carbon-neutral Malaysia beyond Covid'19 pandemic. J. Clean. Prod. 2020, 273, 122834. [CrossRef] [PubMed]

56. Kim, J.H.; Alameri, S.A. Harmonizing nuclear and renewable energy: Case studies. Int. J. Energy Res. 2020, $44,8053-8061$. [CrossRef]

57. Kardooni, R.; Yusoff, S.B.; Kari, F.B. Renewable energy technology acceptance in Peninsular Malaysia. Energy Policy 2016, 88, 1-10. [CrossRef]

58. Sabry, A.H.; Hasan, W.Z.W.; Sabri, Y.H.; Ab-Kadir, M.Z.A. Silicon PV module fitting equations based on experimental measurements. Energy Sci. Eng. 2019, 7, 132-145. [CrossRef]

59. Fadaeenejad, M.; Radzi, M.A.M.; Fadaeenejad, M.; Zarif, M.; Gandomi, Z. Optimization and comparison analysis for application of PV panels in three villages. Energy Sci. Eng. 2015, 3, 145-152. [CrossRef]

60. Izzah, N.; Aziz, H.A.; Hanafiah, M.M. Contents List available at RAZI Publishing the potential of palm oil mill effluent (pome) as a renewable energy. Acta Sci. Malaysia 2017, 1, 9-11.

61. Hanafiah, M.M.; Huijbregts, M.A.J.; Hendriks, A.J. The Influence of Nutrients and Non- $\mathrm{CO}_{2}$ Greenhouse Gas Emissions on the Ecological Footprint of Products. Sustainability 2010, 2, 963-979. [CrossRef]

62. Zakaria, Z.; Kamarudin, S.K.; Abd Wahid, K.A.; Abu Hassan, S.H. The progress of fuel cell for malaysian residential consumption: Energy status and prospects to introduction as a renewable power generation system. Renew. Sustain. Energy Rev. 2021, 144, 110984. [CrossRef]

63. Hannan, M.A.; Begum, R.A.; Abdolrasol, M.G.; Hossain Lipu, M.S.; Mohamed, A.; Rashid, M.M. Review of baseline studies on energy policies and indicators in Malaysia for future sustainable energy development. Renew. Sustain. Energy Rev. 2018, 94, 551-564. [CrossRef]

64. Sutrisno, A.; Nomaler, Ö.; Alkemade, F. Has the global expansion of energy markets truly improved energy security? Energy Policy 2021, 148. [CrossRef]

65. Salehi, A.A.; Ghannadi-Maragheh, M.; Torab-Mostaedi, M.; Torkaman, R.; Asadollahzadeh, M. An overview of sustainable energy development by using cogeneration technology and opportunity for improving process. Int. J. Energy Res. 2020, 1-17. [CrossRef]

66. Pronińska, K.; Księżopolski, K. Baltic Offshore Wind Energy Development-Poland's Public Policy Tools Analysis and the Geostrategic Implications. Energies 2021, 14, 4883. [CrossRef]

67. Şen, Z. Innovative methodologies in renewable energy: A review. Int. J. Energy Res. 2019, 43, 5621-5658. [CrossRef]

68. Yildiz, I. Review of climate change issues: A forcing function perspective in agricultural and energy innovation. Int. J. Energy Res. 2019, 43, 2200-2215. [CrossRef]

69. Singh, V.; Dincer, I.; Rosen, M.A. Investigation of new mechanical heat pump systems for heat upgrading applications. Int. J. Energy Res. 2018, 42, 3078-3090. [CrossRef]

70. Szulecki, K. When Energy Becomes Security: Copenhagen School Meets Energy Studies. Utkast Present. Danish Inst. Int. Stud. 2016, 1-29. Available online: https://www.researchgate.net/profile/Kacper-Szulecki/project/When-energy-becomes-security-The-CopenhagenSchool-meets-energy-studies/attachment/583ebaa108aef5af880132f7/AS:434087853858816@1480506017192/download/Szulecki+ Energy+Securitization+COPENHAGEN+Jun2016.pdf?context=ProjectUpdatesLog (accessed on 20 October 2021).

71. McDonald, M. Securitization and the Construction of Security. Eur. J. Int. Relat. 2008, 14, 563-587. [CrossRef]

72. Balzacq, T. The Three Faces of Securitization: Political Agency, Audience and Context. Eur. J. Int. Relat. 2005, 11, 171-201. [CrossRef]

73. Stritzel, H. Towards a Theory of Securitization: Copenhagen and Beyond. Eur. J. Int. Relat. 2007, 13, 357-383. [CrossRef]

74. Balzacq, T. Securitization Theory: How Security Problems Emerge and Dissolve. Available online: http://www.onacademic. com/detail/journal_1000039846514510_381d.html (accessed on 1 October 2021).

75. Park, H.; Bae, S. Quantitative Assessment of Energy Supply Security: Korea Case Study. Sustainability 2021, 13, 1854. [CrossRef]

76. Sahid, E.J.M.; Sin, T.C. Energy security in ASEAN region: A case study of Malaysia energy security performance with renewable energy implementation. J. Adv. Res. Fluid Mech. Therm. Sci. 2019, 61, 190-201. 
77. Malik, S.; Qasim, M.; Saeed, H.; Chang, Y.; Taghizadeh-Hesary, F. Energy security in Pakistan: Perspectives and policy implications from a quantitative analysis. Energy Policy 2020, 144, 111552. [CrossRef]

78. Yao, L.; Chang, Y. Energy security in China: A quantitative analysis and policy implications. Energy Policy 2014, 67, 595-604. [CrossRef]

79. Abdullah, F.B.; Iqbal, R.; Hyder, S.I.; Jawaid, M. Energy security indicators for Pakistan: An integrated approach. Renew. Sustain. Energy Rev. 2020, 133, 110122. [CrossRef]

80. Martchamadol, J.; Kumar, S. An aggregated energy security performance indicator. Appl. Energy 2013, 103, 653-670. [CrossRef]

81. Kruyt, B.; van Vuuren, D.P.; de Vries, H.J.M.; Groenenberg, H. Indicators for energy security. Energy Policy 2009, 37, $2166-2181$. [CrossRef]

82. Erahman, Q.F.; Purwanto, W.W.; Sudibandriyo, M.; Hidayatno, A. An assessment of Indonesia's energy security index and comparison with seventy countries. Energy 2016, 111, 364-376. [CrossRef]

83. Fang, D.; Shi, S.; Yu, Q. Evaluation of sustainable energy security and an empirical analysis of China. Sustainability 2018, 10, 1685. [CrossRef]

84. Ang, B.W.; Choong, W.L.; Ng, T.S. A framework for evaluating Singapore' s energy security. Appl. Energy 2015, 148, 314-325. [CrossRef]

85. Sovacool, B.K.; Mukherjee, I.; Drupady, I.M.; D’Agostino, A.L. Evaluating energy security performance from 1990 to 2010 for eighteen countries. Energy 2011, 36, 5846-5853. [CrossRef]

86. Sovacool, B.K. Assessing energy security performance in the Asia Pacific, 1990-2010. Renew. Sustain. Energy Rev. 2013, 17, 228-247. [CrossRef]

87. Wu, G.; Liu, L.C.; Han, Z.Y.; Wei, Y.M. Climate protection and China's energy security: Win-win or tradeoff. Appl. Energy 2012, 97, 157-163. [CrossRef]

88. Wang, D.; Tian, S.; Fang, L.; Xu, Y. A functional index model for dynamically evaluating China's energy security. Energy Policy 2020, 147, 111706. [CrossRef]

89. Wang, Q.; Zhou, K. A framework for evaluating global national energy security. Appl. Energy 2017, 188, 19-31. [CrossRef] 